\title{
Investigation of the effect of trisodium-citrate on blood coagulation by viscometric approach
}

\section{TAMÁS CSURKA ${ }^{1,2 *}$ ำ, KLÁRA PÁSZTOR-HUSZÁR ${ }^{1}$, ADRIENN TÓTH ${ }^{1}$, RICHÁRD PINTÉR ${ }^{1,2}$ and LÁSZLÓ FERENC FRIEDRICH ${ }^{1}$}

\begin{abstract}
${ }^{1}$ Szent István University, Faculty of Food Science, Institute of Food Technology, Department of Refrigeration and Livestocks' Products Technology, Ménesi út 43-45, H-1118, Budapest, Hungary

${ }^{2}$ Szent István University, Doctoral School of Food Sciences, Villányi út 29-43, H-1118, Budapest, Hungary
\end{abstract}

\section{CONFERENCE FULL PAPER}

Received: August 13, 2020 • Accepted: October 11, 2020

Published online: November 5, 2020

(C) 2020 The Author(s)

\begin{abstract}
Blood coagulation is a process, which is initiated by certain physico-chemical effects. This process results in a change in the blood from the sol state, that is well suited for further processing, to gel state. 13 blood clotting factors take part in the cascade system of blood coagulation. Trisodium-citrate affects factor IV, the calcium, and prevents the change in blood texture. The effect of different concentrations of trisodiumcitrate $(0,0.48,2.4,4.8,9.6,14.4,19.2,24 \mathrm{w} / \mathrm{w} \%)$ on the texture of blood is investigated. Porcine blood was collected in $20 \mathrm{~cm}^{3}$ test tubes in a slaughterhouse directly before trisodium-citrate addition and was stored for one day under refrigerated conditions. The samples without trisodium-citrate coagulated and the samples with high trisodium-citrate $(4-5 \mathrm{~g})$ became solid as well because of the protein salting-out. The viscosity of successfully treated samples and the shear stress were measured with a rotational viscometer (Physica MCR 51, Anton-Paar) with concentric cylinders and Couette type method. The flow behavior of all samples could be described by the Herschel-Bulkley model. The yield point, the consistency index and the power of law index, which are determined by the equation of the model, showed that the samples with lower trisodium-citrate content coagulated "better" and the sample with high trisodium-citrate were most similar to Newtonian fluid. The results are trend-likes, but significant differences may be expected in the case of higher sample amount. The yield point of the sample, which contained $14.4 \mathrm{w} / \mathrm{w} \%$ trisodium-citrate, was by $37.3 \%$ less than the sample containing $0.48 \%$ trisodium-citrate, and the consistency index of the sample with $3 \mathrm{~g}$ trisodium-citrate was by $20.5 \%$ higher than that of the sample with $0.48 \%$ trisodium-
\end{abstract}

\footnotetext{
*Corresponding author. E-mail: csurka.tamas@szie.hu
} 
citrate. Thanks to these results a cheaper concentration and drying of porcine blood and blood fractions are available because no surplus water is added to the blood.

\section{KEYWORDS}

blood processing, blood coagulation, by-product, trisodium-citrate, viscosimetry

\section{INTRODUCTION}

The utilization of byproducts, especially by-products of animal origin, will be more important than ever before in the near future because of the increasing world population and need of food, especially meat products. Sustainability and utilizing of by-products are hot spots of scientific literature. More sustainable food system also is preferred by consumers (Floros et al., 2010). Utilizing so much animal by-products as we can is necessary because of two important reasons. Substituting of meat with animal by-product is a doubly useful solution. The first reason is the low efficiency of meat production. $7.7 \mathrm{~kg}$ feed and 15,400 L water are required for producing $1 \mathrm{~kg}$ beef, $3.6 \mathrm{~kg}$ feed and 6,000 L water are required for producing $1 \mathrm{~kg}$ pork and $2.2 \mathrm{~kg}$ feed and 3,400 L water are required for producing $1 \mathrm{~kg}$ chicken (Huis, 2010; Mekonnen and Hoekstra, 2010). Carbon footprint of livestock, which estimated to represent $14.5 \%$ of human induced greenhouse gas emission (Gerber et al., 2013; Harwatt et al., 2017), also leads to the necessity of development. Absolute and relative overpopulation is the second reason. Absolute population means the growing of population: more than 9 billion people are predicted by 2050 (Godfray et al., 2010). Relative overpopulation means excessive consumption: population "only" doubled between 1950 and 2000 and the volume of meat production nearly multiplied by five from 45 million t/year to 233 million t/year (Boland et al., 2013). Besides, the infield area can be increased maximum to 1.8 billion hectares, and it was 1.6 billion hectares in 2016 (Godfray et al., 2010). Starving is also a big problem: 795 million people are starving (11\% of population) (McGuire, 2015), while 58 million t protein is consumed in a year by humans from the produced 77 million t protein (Steinfeld et al., 2006). Utilizing of animal blood in high volume may be a solution for iron deficiency anemia, which affects 1.6 billion people (in Africa $64.6 \%$, in Asia 47.7\%, in Europe 16.7\%, in Latin America 39.5\%, in North America 3.4\% and in Oceania 28\% of children.) (Miller, 2013) with more than $1,490 \mathrm{mg}$ iron/kg dry mass (Sorapukdee and Narunatsopanon, 2017; USDA, 2018). Its absorption is better in the human body than the other forms of iron (WHO, 2004). The fascinating fact is that $100 \mathrm{~g}$ porcine blood powder can cover an average $70 \mathrm{~kg}$ adult's daily essential amino acid need except for the methionine (Ockerman and Hansen, 2000). Animal blood may the perfect raw material of food producing in the case of functional as well as common foods (Bah et al., 2013; Duarte et al., 1999; Hsieh and Ofori, 2011; Ofori and Hsieh, 2012; Toldrá et al., 2012). The second reason is the polluting power of this byproduct. Animal blood usually is annihilated instead of further processing, because it has to be handled as hazardous waste. There are criteria for blood collecting and handling in Europe in the Regulation (EC) No 853/2004 of the European Parliament and of the Council on specific hygiene rules for food of animal origin. The biological oxygen demand of blood is about $200 \mathrm{~g} / \mathrm{L}$ and the chemical oxygen demand of blood is about $400 \mathrm{~g} / \mathrm{L}$ (Ofori and Hsieh, 2012). It exceeds the value in Council Directive 91/271/EEC concerning urban waste-water treatment and 
Commission Directive 98/15/EC amending Council Directive 91/271/EEC with respect to certain requirements established in Annex I thereof. Because of the high polluting power, animal blood is the most problematic from animal by-products in slaughterhouses (Lynch et al., 2017). Besides, blood is produced in a very high amount. The weight of extractable blood is $3-4 \%$ of the live animal weight, which is $3-4 \mathrm{~kg}$ per an average pig. The weight of total blood is $5-9 \%$ if the live animal weight, but just about $50 \%$ of this amount is available from the bloodletting because $10 \%$ is in the skin, $16 \%$ is in the spleen and $20 \%$ is in the liver. Besides, capillaries cannot be emptied fully (Gorbatov, 1988; Ockerman and Hansen, 2000).

Blood may be a perfect additive or main component for functional foods because it is a rich source of iron and proteins of high nutritional and functional quality (Putnam, 1975). If we would like to utilize animal blood for human consumption in high amount, it must be separated to plasma and RBC fraction or other blood fractions because the whole blood has dark color and irony taste, which most consumers do not like (Ofori and Hsieh, 2012). Whole blood or other blood products can be spray dried or freeze dried for storage or transportation because the protein rich liquids have very unfavorable shelf-life (Salvador et al., 2009).

Blood coagulation is a process, which is initiated by certain physico-chemical effects. This process results in a change in the blood from the sol state, that is well suited for further processing, to gel state. 13 blood clotting factors take part in the cascade system of blood coagulation (Schmaier and Lazarus, 2011). But the blood coagulation must be inhibited directly following blood collection before any other preservation technologies would be used. The coagulated blood cannot be handled in a closed pipe system and its important technological attributes are lost. $10 \mathrm{w} / \mathrm{w} \%$ sodium-citrate solution is added in $0.24 \mathrm{w} / \mathrm{w} \%$ to the fresh whole blood for inhibiting blood coagulation in most places, according to the old industrial recommendation (Gárgyán, 1991). But if water is added into blood, the concentration and drying process will be slower and more expensive. Water is added into the blood, which has to be removed. Blood coagulation can be inhibited by EDTA or other substances, for instance heparin or vitamin $\mathrm{K}$ antagonists (coumarins), but trisodium-citrate is preferred in the case of food industry. The group of sodiumcitrates is a licensed food additive, which may be used in prepared meat products without quantitative restrictions according to the Regulation (EC) No 1333/2008 of the European Parliament and of the Council on food additives. It is marked with "E 331". Calcium-disodiumEDTA has also a mark, which is "E 385", but the limitation is low and strict.

The aim was of the study was making blood processing and preservation more efficient by development of blood coagulation inhibiting. The essence of development is that no surplus water is added to the blood before concentrating and drying. This required that the effect of dry trisodium-citrate powder on the coagulation of whole animal blood was investigated in this study. The change in blood texture was measured by viscometric approach. If small amount of dry trisodium-citrate powder can inhibit blood coagulation in industrial environment, the water content of blood may be lower before the following processes.

\section{MATERIAL AND METHODS}

\section{Blood collection and the addition of anticoagulant}

Porcine blood was collected manually in a slaughterhouse directly from the slaughtered pork in South Transdanubia during the bloodletting. Type of pigs (Sus scrofa domesticus) were 
mangalica $\times$ duroc hybrid. $20 \mathrm{~cm}^{3}$ test tubes were used as sample holder. The trisodium-citrate (Reanal Laborvegyszer Kft., Hungary) was added to the blood directly after collection; then the substances were mixed well. The samples were mixed with different amounts of trisodiumcitrate: $0,0.1,0.5,1,2,3,4,5 \mathrm{~g}$. If we calculated with the density of porcine blood, which is $1,040 \mathrm{~kg} / \mathrm{m}^{3}$ (Kowalski et al., 2011), the trisodium-citrate content of the samples were the following: $0,0.48,2.4,4.8,9.6 / \mathrm{w} \%, 14.4 / \mathrm{w} \%, 19.2,24 \mathrm{w} / \mathrm{w} \%$. The prepared samples were stored in test tubes for one day under refrigerated condition before the measurements. Three parallel samples were prepared for the investigation.

\section{Flow behavior}

An Anton-Paar Physica MCR 91 (Anton-Paar GmbH, Germany) viscosimeter device was used for the investigation. Samples with $1 \mathrm{w} / \mathrm{w} \%$ trisodium-citrate were coagulated and protein content of samples with $24 \mathrm{w} / \mathrm{w} \%$ trisodium-citrate was salting-out. Because of the different rheological behaviors, these samples cannot be compared to other samples, and that is why the previously mentioned samples could not be measured. The viscosity of measurable samples and the shear stress were measured with a Couette concentric cylinders (CC27) set up. The samples were tempered to $20{ }^{\circ} \mathrm{C}$ during the measurement. The outcome of the measurement was a flow curve, to which a model was fitted. Data were collected between 10 and 1,000 $\mathrm{min}^{-1}$ shear rate and the flow behavior of all samples could be described by the Herschel-Bulkley model (Mezger, 2006), which considers the following parameters: shear stress $(\tau)$, theoretical yield point $\left(\tau_{0}\right)$, deformation speed $(\gamma)$, consistency index $(C)$ and power of law index $(p)$. The parameters were calculated from the shear rate and shear stress.

Equation (1) $\tau=\tau_{0}+C \times \gamma^{p}$ (Mezger, 2006).

A new shear rate was calculated based on these parameters. Based on the difference of measured and calculated shear rate, the compliance of the model can be validated or rejected. The determination coefficient $\left(R^{2}\right)$ shows how appropriate a model is. The determination coefficient shows a very appropriate model.

Data are evaluated by the comparison of attributes' expected values and Pearson correlation analysis, which measure the dependence between two quantities. The Pearson correlation coefficient $(r)$ shows the strength of the change. The ' 1 ' value shows straight ratio and the ' -1 ' value shows inverse ratio. Notations and dimensions, which are used in this paper, are shown in Table 1.

\section{RESULTS}

The yield point, the consistency index and the power of law index, which are determined by the equation of the used model, showed that the samples with lower trisodium-citrate content coagulated "better" and the samples with high trisodium-citrate were most similar to Newtonian fluid. In the case of Newtonian fluid, the value of consistency index is positive, the value of yield point is 0 and the value of power of law index is 1 . Newtonian fluids can be handled more simply and cheaper because the energy consumption of fluid flow in a pipe system depends on the viscosity of the fluid, which depends on the shear stress (Xie et al., 2016). This shear stress dependence is more advantageous in the case of Newtonian fluid. Besides, the more the fluid differs from Newtonian fluid, the more coagulated parts the fluid contains. 
Table 1. Nomenclature

\begin{tabular}{lcc}
\hline Notation & Dimension used in this paper & Name \\
\hline $\mathrm{W}$ & $\mathrm{w} / \mathrm{w} \%$ & Mass percent \\
$\tau$ & $\mathrm{Pa} \mathrm{s}$ & Shear stress \\
$\tau_{0}$ & $\mathrm{~Pa} \mathrm{~s}$ & Yield stress \\
$\mathrm{C}$ & $\mathrm{Pa} \mathrm{s}^{\mathrm{p}}$ & Consistency index \\
$\gamma$ & $\mathrm{s}^{-1}$ & Shear rate \\
$\mathrm{p}$ & - & Power of law index/Flow behavior index \\
$\mathrm{R}^{2}$ & - & Determination coefficient \\
$\mathrm{r}$ & - & Pearson correlation coefficient \\
\hline
\end{tabular}

Table 2. Calculated constants of Herschel-Bukley model of measurable porcine blood samples with different trisodium-citrate

\begin{tabular}{lcccc}
\hline $\mathrm{Na}_{3}$-citrate $(\mathrm{w} / \mathrm{w} \%)$ & $\tau_{0}(\mathrm{~Pa})$ & $\mathrm{C}\left(\mathrm{Pa} \mathrm{s}^{\mathrm{p}}\right)$ & $\mathrm{p}(-)$ & $\mathrm{R}^{2}(-)$ \\
\hline 0.48 & 0.658 & $2.49 \mathrm{E}-03$ & 1.22 & 0.999 \\
2.4 & 0.346 & $8.95 \mathrm{E}-04$ & 1.34 & 0.995 \\
4.8 & 0.268 & $3.33 \mathrm{E}-03$ & 1.17 & 0.997 \\
14.4 & 0.279 & $8.19 \mathrm{E}-04$ & 1.36 & 0.997 \\
19.2 & 0.246 & $1.21 \mathrm{E}-02$ & 1.03 & 0.999 \\
\hline
\end{tabular}

Some results, which have been obtained from the comparison of the attributes' expected values, are introduced in the following and shown in Table 2. The results are trend-likes, but significant differences may be expected in the case of higher sample amount. The yield point of the sample, which contained $14.4 \mathrm{w} / \mathrm{w} \%$ trisodium-citrate, was by $37.3 \%$ less than that of the sample containing $0.48 \mathrm{w} / \mathrm{w} \%$ trisodium-citrate, and the consistency index of the sample with $14.4 \mathrm{w} / \mathrm{w} \%$ trisodium-citrate was by $20.5 \%$ higher than that of the sample with $0.48 \mathrm{w} / \mathrm{w} \%$ trisodium-citrate. It can be described generally that the sample, which contains $0.48 \%$ trisodium-citrate, was least similar to Newtonian fluid and the other samples were similar to each other in terms of yield point, consistency index and power of law index. The correlation coefficients of the used model were higher than 0.995 so the model, that was used for calculating the parameters, was appropriate.

The correlation between the trisodium-citrate concentration and yield point $(r=-0.66)$ and between the trisodium-citrate concentration and consistency index $(r=0.66)$ were moderately strong. But in the case of biological samples, values over 0.6 are considered to have a good relation. The samples without trisodium-citrate (control samples) coagulated and the samples with high trisodium-citrate content $(19.2-24 \mathrm{w} / \mathrm{w} \%)$ became solid as well. The proteins of samples with high trisodium-citrate were probably salting-out. The $\mathrm{pH}$ cannot reach the isoelectric point of proteins because the trisodium-citrate is alkaline and the isoelectric point of the main blood proteins is in the acidic region. Besides, there was a solid layer on the surface of the sample with $0.48 \%$ trisodium-citrate, which had to be removed before the measurement. 


\section{CONCLUSION}

Water content of blood has to be removed for better use and preservation purposes. But before water removal an anticoagulant, which fits for food industrial use, has to be added into the blood. This study recommends adding dry trisodium-citrate powder instead of adding its water solution. The least sodium-citrate content, which is able to inhibit blood coagulation for one day, is $2.4 \%$ according to the results of this study. If a firm collects animal blood for drying or producing blood products with low water content, it is advantageous to use dry sodium-citrate powder instead of a liquid solution. Based on these results, a cheaper and faster water removal, which means membrane concentration and spray drying or lyophilization, of the porcine blood and blood fractions are available, because it is not necessary to add water (from a solution) into the blood.

\section{ACKNOWLEDGMENT}

Supported by the ÚNKP-19-3-I-SZIE-58. New National Excellence Program of the Ministry for Innovation and Technology and the Szent István University, Doctoral School of Food Sciences.

\section{REFERENCES}

Bah, C.S., Bekhit, A.E.D.A., Carne, A., and McConnell, M.A. (2013). Slaughterhouse blood: an emerging source of bioactive compounds. Comprehensive Reviews in Food Science and Food Safety, 12(3): 314331.

Boland, M.J., Rae, A.N., Vereijken, J.M., Meuwissen, M.P., Fischer, A.R., van Boekel, M.A., Rutherfurd, S.M., Gruppen, H., Moughan, P.J., and Hendriks, W.H. (2013). The future supply of animal-derived protein for human consumption. Trends in Food Science \& Technology, 29(1): 62-73.

Commission Directive 98/15/EC of 27 February 1998 amending Council Directive 91/271/EEC with respect to certain requirements established in Annex I thereof.

Council Directive 91/271/EEC of 21 May 1991 concerning urban waste-water treatment.

Duarte, R.T., Carvalho Simões, M.C., and Sgarbieri, V.C. (1999). Bovine blood components: fractionation, composition, and nutritive value. Journal of Agricultural and Food Chemistry, 47(1): 231-236.

Floros, J.D., Newsome, R., Fisher, W., Barbosa-Cánovas, G.V., Chen, H., Dunne, C.P., German, J.B., Hall, R.L., Heldman, D.R., Karwe, M.V. (2010). Feeding the world today and tomorrow: the importance of food science and technology. Comprehensive Reviews in Food Science and Food Safety, 9: 572-599.

Gárgyán, Z. (1991). Húsipari technológia I. Dinasztia Kft, Budapest.

Gerber, P.J., Steinfeld, H., Henderson, B., Mottet, A., Opio, C., Dijkman, J., Falcucci, A., and Tempio, G. (2013). Tackling climate change through livestock: a global assessment of emissions and mitigation opportunities. Food and Agriculture Organization of the United Nations (FAO).

Godfray, H.C.J., Beddington, J.R., Crute, I.R., Haddad, L., Lawrence, D., Muir, J.F., Pretty, J., Robinson, S., Thomas, S.M., and Toulmin, C. (2010). Food security: the challenge of feeding 9 billion people. Science, 327(5967): 812-818. 
Gorbatov, V.M. (1988). Collection and utilization of blood and blood proteins for edible purposes in the USSR. Advances in Meat Research, 5: 167-195 (USA).

Harwatt, H., Sabaté, J., Eshel, G., Soret, S., and Ripple, W. (2017). Substituting beans for beef as a contribution toward US climate change targets. Climatic Change, 143(1): 261-270.

Hsieh, Y.H.P. and Ofori, J.A. (2011). Blood-derived products for human consumption. Revelation and Science, $1(1)$.

Huis, V.A. (2010). Opinion: Bugs can solve food crisis. The Scientist - Magazine of the Life Sciences.

Kowalski Z., Makara A., and Banach M. (2011). Blood plasma and hemoglobin production process. Chemik, 65(5): 466-475.

Lynch, S.A., Mullen, A.M., O'Neill, E.E., and García, C.Á. (2017). Harnessing the potential of blood proteins as functional ingredients: A review of the state of the art in blood processing. Comprehensive Reviews in Food Science and Food Safety, 16(2): 330-344.

McGuire, S. (2015). FAO, IFAD, and WFP. The state of food insecurity in the world 2015: meeting the 2015 international hunger targets: taking stock of uneven progress. FAO, Rome.

Mekonnen, M.M. and Hoekstra, A.Y. (2010). The green, blue and grey water footprint of farm animals and animal products. Volume 2: Appendices.

Mezger, T.G. (2006). The rheology handbook: for users of rotational and oscillatory rheometers. Vincentz Network GmbH \& Co KG.

Miller, J.L. (2013). Iron deficiency anemia: a common and curable disease. Cold Spring Harbor Perspectives in Medicine, 3(7): a011866.

Ockerman, H.W. and Hansen, C.L. (2000). Animal byproduct processing and utilization. Lancaster Technomic Publishing Company Inc.

Ofori, J.A. and Hsieh, Y.H.P. (2012). The use of blood and derived products as food additives. In: Food additive. IntechOpen.

Putnam, F.W. (1975). The plasma proteins: structure, function, and genetic control. Academic Press, New York.

Regulation (EC) No 1333/2008 of the European Parliament and of the Council of 16 December 2008 on food additives.

Regulation (EC) No 853/2004 of the European Parliament and of the Council of 29 April 2004 laying down specific hygiene rules for food of animal origin.

Salvador, P., Toldrà, M., Parés, D., Carretero, C., and Saguer, E. (2009). Color stabilization of porcine hemoglobin during spray-drying and powder storage by combining chelating and reducing agents. Meat Science, 83(2): 328-333.

Schmaier, A.H. and Lazarus, H.M. (2011). Concise guide to hematology. John Wiley \& Sons.

Sorapukdee, S. and Narunatsopanon, S. (2017). Comparative study on compositions and functional properties of porcine, chicken and duck blood. Korean Journal for Food Science of Animal Resources, 37(2): 228.

Steinfeld, H., Gerber, P., Wassenaar, T.D., Castel, V., Rosales, M., Rosales, M., and de Haan, C. (2006). Livestock's long shadow: environmental issues and options. Food \& Agriculture Org.

Toldrá, F., Aristoy, M.C., Mora, L., and Reig, M. (2012). Innovations in value-addition of edible meat byproducts. Meat Science, 92(3): 290-296.

USDA, United States Department of Agriculture, Agricultural Research Service, Nutrient Data Laboratory. (2018). USDA National Nutrient Database for Standard Reference, Release 29.

World Health Organization. (2004). Vitamin and mineral requirements in human nutrition. World Health Organization. 
Xie, F., Chen, W., Wang, J., and Liu, J. (2016). CFD and experimental studies on the hydrodynamic performance of submerged flat-sheet membrane bioreactor equipped with micro-channel turbulence promoters. Chemical Engineering and Processing: Process Intensification, 99: 72-79.

Open Access. This is an open-access article distributed under the terms of the Creative Commons Attribution 4.0 International License (https://creativecommons.org/licenses/by/4.0/), which permits unrestricted use, distribution, and reproduction in any medium, provided the original author and source are credited, a link to the CC License is provided, and changes - if any - are indicated. (SID_1) 